\title{
Yew and juniper pollen season in the air of Poland in 2019
}

\author{
Małgorzata Puc ${ }^{1,2}$, Daniel Kotrych ${ }^{3}$, Małgorzata Malkiewicz ${ }^{4}$, Katarzyna Dąbrowska-Zapart5, \\ Dorota Myszkowska', Agata Konarska ${ }^{7}$, Agnieszka Lipiec ${ }^{8}$, Adam Rapiejko ${ }^{9}{ }^{10}$, Zenon Siergiejko"11, \\ Dariusz Jurkiewicz ${ }^{12}$, Anna Wierzbicka-Rot ${ }^{13}$, Piotr Rapiejko' ${ }^{12}$, Alina Stacewicz ${ }^{2}$ \\ ${ }^{1}$ Institute of Marine \& Environmental Sciences, University of Szczecin, Poland \\ ${ }^{2}$ Department of Botany and Nature Conservation, Faculty of Biology, University of Szczecin, Poland \\ ${ }^{3}$ Department of Orthopedics and Traumatology, Pomeranian Medical University of Szczecin, Poland \\ ${ }^{4}$ Department of Palaeobotany, Institute of Geological Sciences, University of Wroclaw, Poland \\ ${ }^{5}$ Department of Paleontology and Stratigraphy, Faculty of Earth Sciences, University of Silesia, Poland
}

${ }^{6}$ Department of Clinical and Environmental Allergology, Medical College, Jagiellonian University, Cracow, Poland ${ }^{7}$ Subdepartment of Aerobiology, Department of Botany and Plant Physiology, University of Life Sciences in Lublin,

Poland

${ }^{8}$ Department of Prevention of Environmental Hazards and Allergology, Medical University of Warsaw, Poland

${ }^{9}$ Allergen Research Center, Warsaw, Poland

${ }^{10}$ Oxford Archaeology Ltd., Oxford, England

${ }^{11}$ Laboratory of Respiratory Diagnostics and Bronchoscopy, Medical University of Bialystok, Poland

${ }^{12}$ Department of Otolaryngology with Division of Cranio-Maxillo-Facial Surgery in Military Institute of Medicine,

Warsaw, Poland

${ }^{13}$ Department of Pediatry, St. Anna's Hospital, Piaseczno, Poland

\begin{abstract}
:
The study compares the yew and juniper pollen seasons in Bialystok, Bydgoszcz, Cracow, Katowice, Piotrkow Trybunalski, Opole, Szczecin, Zielona Gora, Warsaw, Wroclaw and Lublin in 2019. The investigations were carried out using the volumetric method (Hirst type pollen sampler). Seasonal Pollen Index (SPI) was estimated as the sum of daily average pollen concentrations in the given season. The yew pollination is mainly observed in February and March, while juniper pollination is mainly observed in March and April. Due to the morphological similarity of the pollen grains of both taxa, the pollen seasons of yew and juniper are considered together. The pollen season of yew/juniper started first in Szczecin, on the February 22nd. At the latest, a pollen season ended in Bialystok, Bydgoszcz, Zielona Gora, Warsaw and Lublin at the end April. The differences of pollen seasons duration were very considerable, from 20 to 63 days. The highest airborne concentration of 784 pollen grains $/ \mathrm{m}^{3}$ was noted in Wroclaw on the March $7^{\text {th }}$. The maximum values of seasonal pollen count occurred between March $4^{\text {th }}$ and $3^{11^{\text {th }}}$. The highest yew and juniper pollen allergen hazard occurred in 2019 in Lublin and Wroclaw and it was at least twice as high as other cities.
\end{abstract}

Key words: aeroallergens, pollen count, yew (Taxus baccata), juniper (Juniperus sp.), 2019

T he growing trend in the incidence of allergic diseases is observed in the industrialized world and has been documented in the literature [1-3]. The clinical data reveals a general increase in both incidence and prevalence of respiratory diseases. Such phenomena may be related not only to air pollution and changes in lifestyle, but also to an actual increase in airborne quantities of allergenic pollen. For example, the year 2019 turned out to be record-breaking in the case of concentrations of alder pollen in Szczecin in comparison with data from the last 20 years. The yew and juniper pollen season in 2019 turned out to be very abundant in Wroclaw and Lublin, especially in relation to the maximum values of daily concentrations. In addition, pollen from yew plants is considered a minor offender in allergenicity. Japanese research proved there were significant reactions among skin-tested patients for yew pollen allergens, while cross-reactions 
with food were not apparent up to now for this plant group [4].

Taxus baccata $\mathrm{L}$. is the only species occurring in the Europe and in Poland. In our country yew is a rare species and is under protection. Yew does not tolerate frosty areas and is sensitive to wide fluctuations of temperatures, droughts and to desiccation by winter winds. It tolerates air pollution well and even withstands toxic industrial emissions. Yew is a wind-pollinated species, flowering rather abundantly. Investigations into the rate of fall of its pollen grains in still air suggest that they can remain airborne for a relatively long time. Studies of surface samples coming from a transect placed under a male specimen of Taxus baccata reveal that the majority of its pollen grains fall directly under the tree. Only a few have been recorded beyond the extent of its crown [5]. These restrictions make the concentration of yew pollen recorded in monitoring much lower than in the immediate vicinity of the pollination source.

Juniperus is the only native genus representing the Cupressaceae family growing in Poland and in the other areas of central Europe. Juniper finds its most favorable conditions in mesotrophic habitats, on dry and slightly moist; this species is able to colonise poor habitats such as sandy wasteland, dunes and heath sites. $J$. communis is a pioneer species. It is found in abandoned fields and pastures, where it plays an essential role in the process of secondary succession. In Poland the main season for juniper pollen production is in April [6].

In the yew pollen grains there is among others diterpenic alkaloid paclitaxel belonging to taxine, which has allergenic properties. Anti-paclitaxel IgG were above all detected in sera of subjects displaying hypersensitivity reactions during the pollination periods of Taxus sp. and Betula sp. This natural anti-paclitaxel IgG acquisition by individuals living in the distribution areas of these trees could be at the origin of atopic manifestations [7]. While in USA yew and juniper pollen is considered extremely allergenic, with an OPALS allergy scale rating of 10 out of 10 (Ogren Plant Allergy Scale - a plant-allergy ranking system used by the United States Department of Agriculture) [8]. For example, birch pollen in this scale rating 9. Allergies to conifer pollen (cypress, juniper, thuja, false cypress, some exotic species of pine trees, Japanese cedar) are little known in Europe: in UK no allergy has been reported for English Yew (Taxus baccata) species and juniper, however, they are an increasing problem in Mediterranean regions.

The threshold value for clinical symptoms for yew and juniper pollen grains in Europe, for the many of sensitised patients is visible during exposure to the concentration of 16 pollen grains in $1 \mathrm{~m}^{3}$ of air, while the clinical symptoms for the most of sensitised patients is visible during exposure to the concentration of 91 pollen grains in $1 \mathrm{~m}^{3}$ of air [9].

\section{Aim}

The aim of the study was to compare the yew/ juniper pollen concentrations in the air of Bialystok, Bydgoszcz, Cracow, Katowice, Piotrkow Trybunalski, Opole, Szczecin, Zielona Gora, Warsaw, Wroclaw and Lublin in 2019 and indication of the highest risk of pollen allergens in individual cities.

\section{Material and method}

Measurements of bioaerosols were carried out in the selected cities of Poland, in Bialystok, Bydgoszcz, Cracow, Katowice, Piotrkow Trybunalski, Opole, Szczecin, Zielona Gora, Warsaw, Wroclaw and Lublin in 2019. Measurements were performed by the volumetric method. The used devices, which are recommended by the IAA (International Association for Aerobiology), take air samples (Burkard and Lanzoni as the Hirst type pollen sampler) in volumes corresponding to average human respiratory parameters.

The duration of the pollen season was determined by the $98 \%$ method [10], assuming that the onset and end of the season were days with recorded $1 \%$ and $99 \%$ of the annual total of pollen grains, respectively. Due to the morphological similarity of the pollen grains of yew and juniper, the pollen seasons of both taxa are considered together.

The total pollen count over this period was expressed by the SPI (Seasonal Pollen Index).

On the basis of literature data, the number of days was determined in which concentrations of pollen of the Cupressaceae family exceed the threshold values of consecutive allergy symptoms' development (tab. 1) [9].

\section{Results and discussion}

In Poland, yew and juniper pollination periods usually coincide with each other in March, because the yew pollination is mainly observed in February and March, while juniper pollination is mainly observed in March and April. Due to the morphological similarity of the pollen grains of both taxa, the pollen seasons of yew and juniper are considered together. Figures 1-6 of this paper clearly show a decrease in the pollen 
Table 1. Characteristics of yew and juniper pollen season in 2018.

\begin{tabular}{|c|c|c|c|c|c|c|c|c|c|c|c|}
\hline $\begin{array}{l}\text { Features of pollen } \\
\text { season/city }\end{array}$ & Bialystok & $\begin{array}{l}\text { Byd- } \\
\text { goszcz }\end{array}$ & Cracow & Katowice & $\begin{array}{l}\text { Piotrkow } \\
\text { Tryb. }\end{array}$ & Opole & Szczecin & $\begin{array}{l}\text { Zielona } \\
\text { Gora }\end{array}$ & Warsaw & Wroclaw & Lublin \\
\hline $\begin{array}{c}\text { Duration of } \\
\text { pollen season } \\
\text { (number of days) }\end{array}$ & $\begin{array}{l}3 \mathrm{III-} \\
27 \mathrm{IV} \\
(56)\end{array}$ & $\begin{array}{l}1 \mathrm{III-} \\
27 \mathrm{IV} \\
(58)\end{array}$ & $\begin{array}{l}28 \mathrm{II} \\
19 \mathrm{IV} \\
(20)\end{array}$ & $\begin{array}{l}28 \mathrm{II}- \\
26 \mathrm{IV} \\
(58)\end{array}$ & $\begin{array}{l}26 \mathrm{II}- \\
24 \mathrm{IV} \\
(58)\end{array}$ & $\begin{array}{l}27 \text { II- } \\
21 \text { IV } \\
(54)\end{array}$ & $\begin{array}{l}22 \mathrm{II-} \\
13 \mathrm{IV} \\
(51)\end{array}$ & $\begin{array}{l}24 \mathrm{II}- \\
27 \mathrm{IV} \\
(63)\end{array}$ & $\begin{array}{l}28 \mathrm{II}- \\
27 \mathrm{IV} \\
(59)\end{array}$ & $\begin{array}{l}28 \text { II- } \\
2 \text { IV } \\
(34)\end{array}$ & $\begin{array}{l}5 \mathrm{III-} \\
27 \mathrm{IV} \\
(54)\end{array}$ \\
\hline $\begin{array}{l}\text { Seasonal Pollen } \\
\text { Index-SPI } \\
\text { (total) }\end{array}$ & 750 & 1177 & 1003 & 603 & 1946 & 2094 & 2197 & 2486 & 2076 & 2369 & 3851 \\
\hline $\begin{array}{l}\text { Peak value and } \\
\text { peak date }\end{array}$ & $\begin{array}{c}34 \\
(18 \mathrm{III})\end{array}$ & $\begin{array}{c}153 \\
(17 \mathrm{III})\end{array}$ & $\begin{array}{l}248 \\
(4 \mathrm{III})\end{array}$ & $\begin{array}{l}118 \\
(8 \mathrm{III})\end{array}$ & $\begin{array}{l}267 \\
(8 \mathrm{III})\end{array}$ & $\begin{array}{l}325 \\
(7 \mathrm{III})\end{array}$ & $\begin{array}{l}351 \\
(7 \mathrm{III})\end{array}$ & $\begin{array}{l}364 \\
(5 \mathrm{III})\end{array}$ & $\begin{array}{c}278 \\
(17 \mathrm{III})\end{array}$ & $\begin{array}{l}784 \\
(7 \mathrm{III})\end{array}$ & $\begin{array}{c}775 \\
(31 \mathrm{III})\end{array}$ \\
\hline $\begin{array}{c}\text { Days } \geq 16 \mathrm{~g} / \mathrm{m}^{3} \\
{[4]^{*}}\end{array}$ & 7 & 21 & 8 & 10 & 27 & 24 & 27 & 25 & 27 & 13 & 31 \\
\hline $\begin{array}{c}\text { Days } \geq 91 \mathrm{~g} / \mathrm{m}^{3} \\
{[4]^{\star \star}}\end{array}$ & 0 & 1 & 4 & 1 & 4 & 6 & 6 & 7 & 6 & 5 & 9 \\
\hline
\end{tabular}

* symptoms present in many patients ** symptoms present in most patients.

Figure 1. Yew and juniper pollen count in Bialystok and Bydgoszcz in 2019.

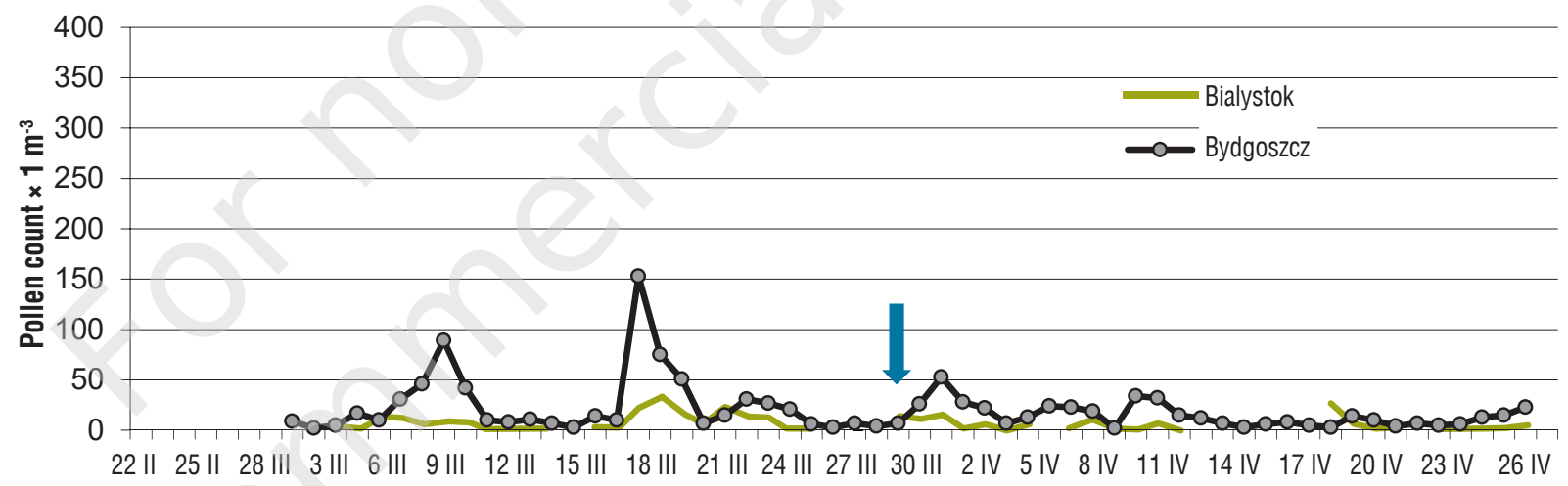

Figure 2. Yew and juniper pollen count in Cracow and Katowice in 2019.

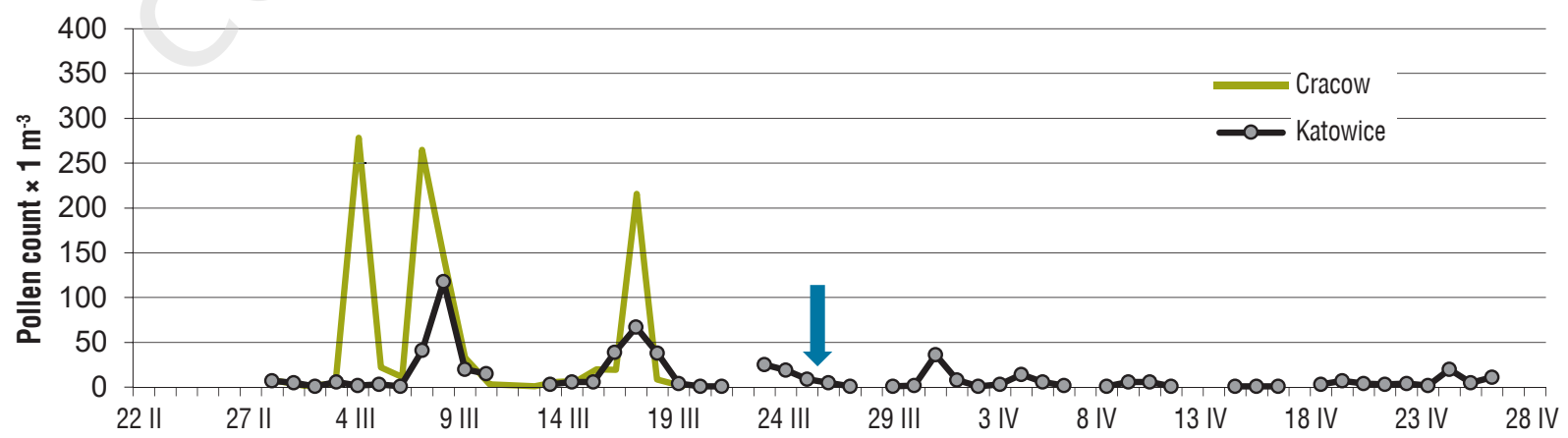

Figure 3. Yew and juniper pollen count in Piotrkow Trybunalski and Opole in 2019.

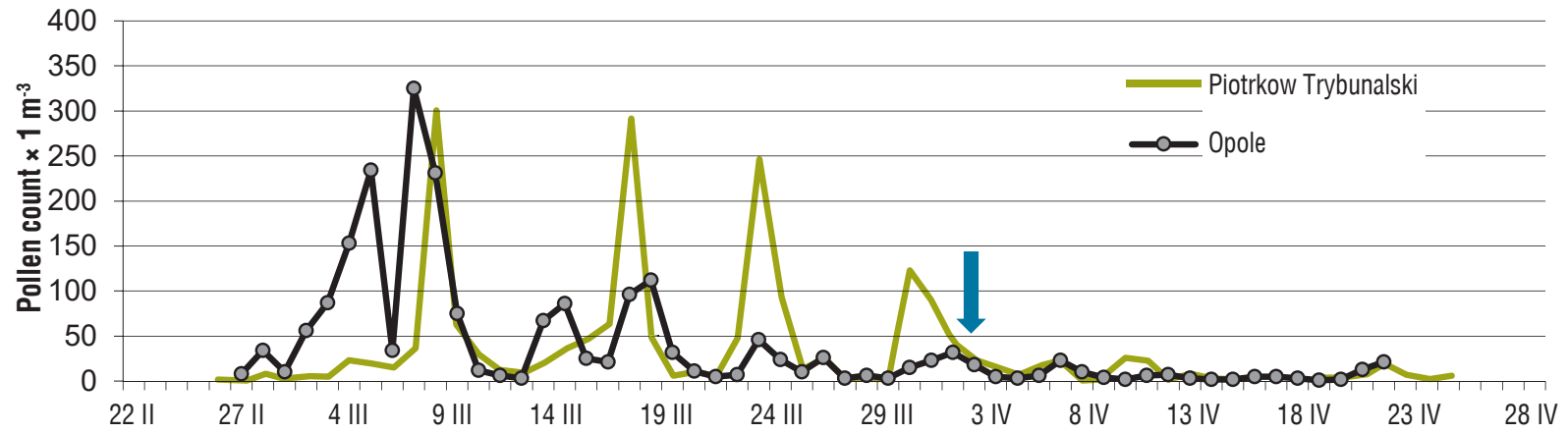


Figure 4. Yew and juniper pollen count in Szczecin and Zielona Gora in 2019.

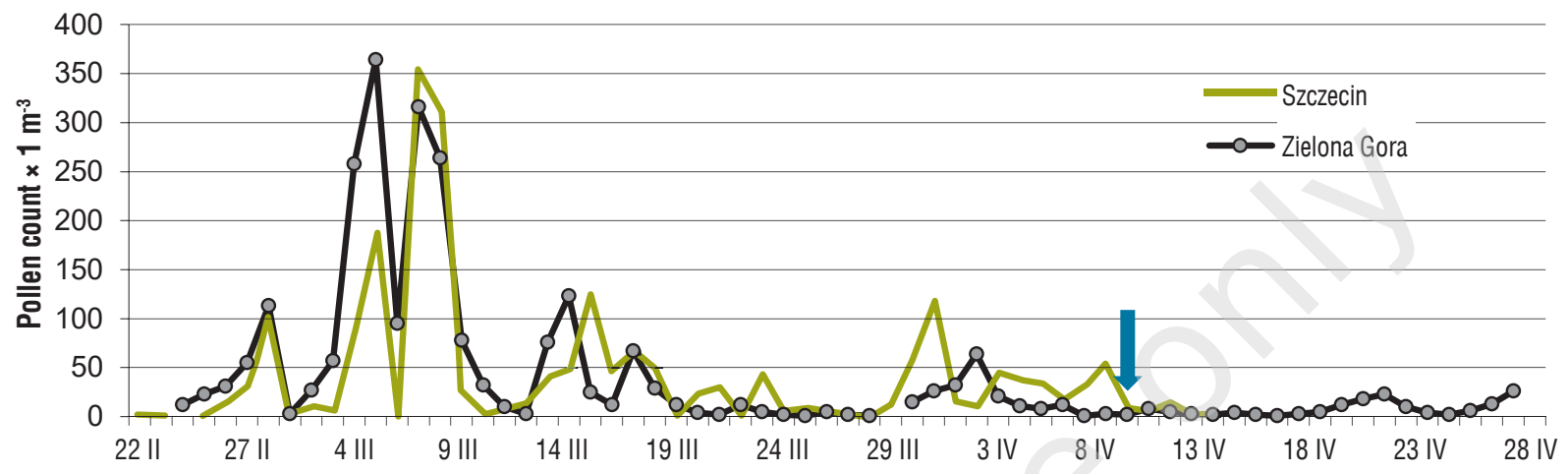

Figure 5. Yew and juniper pollen count in Warsaw in 2019.

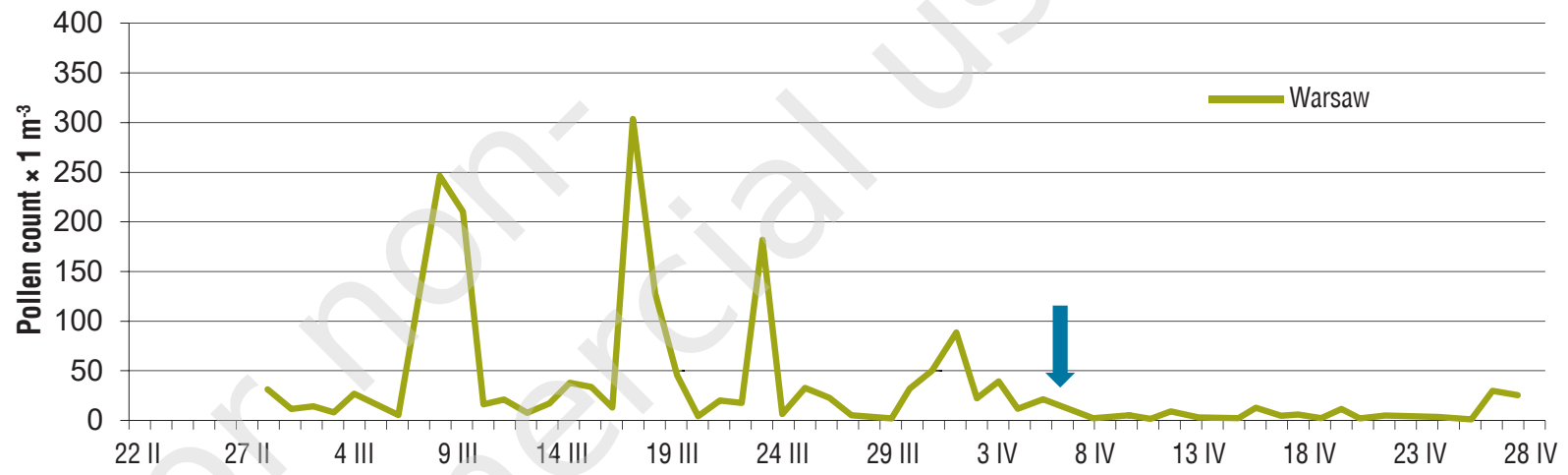

Figure 6. Yew and juniper pollen count in Wroclaw and Lublin in 2019.

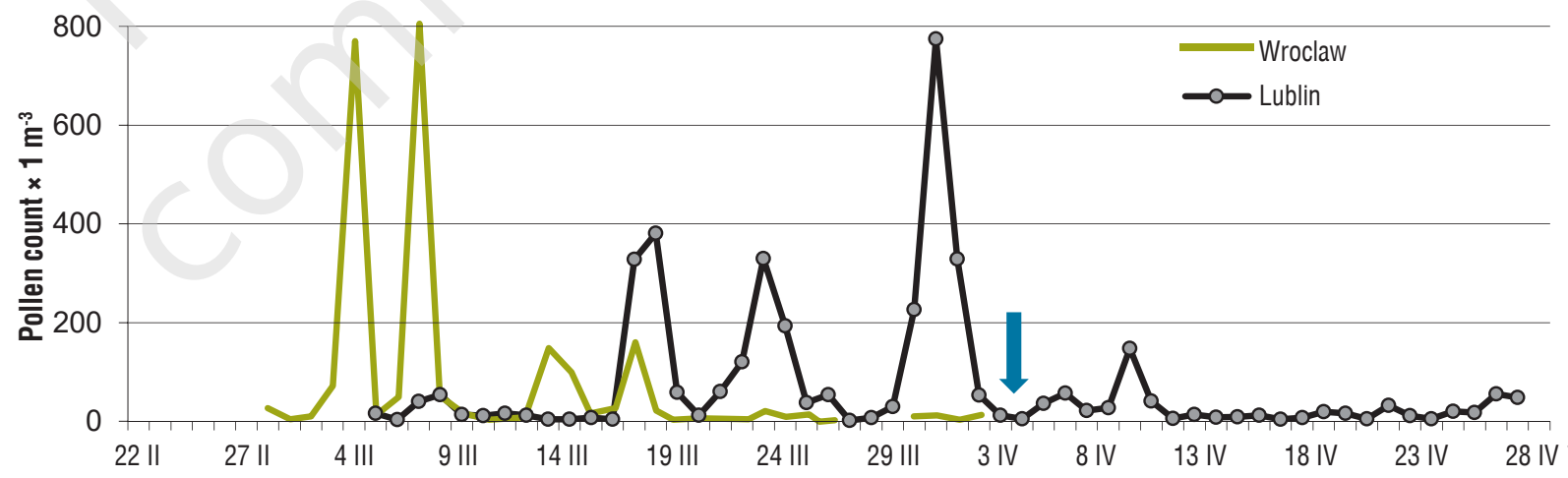

Blue arrow - estimated decrease in pollen concentration at the turn of March and April.

concentration of these plants at the turn of March and April, when the yew pollination period usually ends and in the air there is mainly pollen from juniper and other Cupressaceae (Thuja, Chamaecyparis, Taxodium, Cryptomeria, Thujopsis) often planted in parks and home gardens beyond their natural geographical range.

In Hokkaido, Taxus cuspidata (Japanese yew) usually started its flowering early April or mid April approximately two weeks before the beginning of birch flowering [11]. Authors of this paper [11] reported, that Japanese yew pollen is not a major pollen causing pollinosis; this pollen is a minor allergen that causes nasal allergy in early spring, in Japan. In Texas, Oklahoma, and New Mexico juniper pollen is a major allergen. While the bulk of pollen may be released in rural areas, large amounts of pollen can be transported to urban areas. Major juniper species in the region include: $J u$ niperus ashei, J. virginiana, J. pinchotii, and J. monosperma. Pollen release is virtually continuous beginning in late September with $J$. pinchotii and ending in May with $J$. monosperma. Urban areas in this region were evaluated for the potential of overlapping seasons in order to inform sensitive individuals [12].

In 2019 yew/juniper pollen season started between February $22^{\text {nd }}$ and April $5^{\text {th }}$ and lasted until the end of April. In 2007 the Taxus/Juniperus pollen 
season in most Polish cities started the earliest at the beginning of March in Wroclaw [13], i.e. 1 week later than in 2019 (tab. 1, figs. 1-6). Comparison of the onset of pollen season in Polish cities in 2009 [14] and 2019 showed a tendency towards acceleration of the beginning of the season in 2019 by about 2-3 weeks.

The highest daily pollen count of yew/juniper was noted in 2019 in Wroclaw on March $7^{\text {th }}\left(784 \mathrm{~g} / \mathrm{m}^{3}\right)$ (tab. 1, fig. 6) and the highest annual sum of Taxus/ Cupressaceae pollen grains (SPI) was observed in Lublin; in other cities SPI value was much lower (the lowest value in Białystok SPI - 750). In 2007 the maximum daily concentration was observed March $13^{\text {th }}$ in Szczecin [13], and in 2009 [14] - March $31^{\text {st }}$ also in Szczecin.

The highest yew/juniper pollen allergen hazard occurred (above $91 \mathrm{~g} / \mathrm{m}^{3}$ ) in Lublin - 9 days. In other cities that value ranged from 0 to 7 days. The comparison of these taxa's pollen seasons in previous years revealed that in 2009 [14] pollen concentrations were much lower.

Considering the possibility of exacerbation of allergy symptoms in urban areas, it should be remembered that people who suffer from hay fever will likely be more sensitive to cigarette smoke. Hay fever sufferers who also suffer from asthma will be particularly susceptible to the effects of smoke on their lungs, eyes and nose. The banning of smoking in many public areas may have been a welcome relief for those who suffer from allergies. However, in Poland in many places the smoking ban is not respected, that's why you may need to avoid the areas where smoke strongly permeates the air.

\section{Conclusions}

The concentration of pollen of the analysed plants decreases markedly at the turn of March and April, yew pollination period usually ends, and in the air mainly pollen of juniper and other Cupressaceae occurs.

Yew/juniper pollen season in most cities was above 50 days long (only in Cracow - 20 days and in Wroclaw - 34 days) and was characterized by different total annual pollen SPI (from 603 to 3851).

The start of Cupressaceae pollen season in 2019 occurred in the end of February or in the beginning of March and lasted to the end of April.

The highest yew/juniper pollen allergen hazard occurred in 2019 in Lublin, Zielona Gora, Warsaw and Szczecin.
The concentration of Cupressaceae pollen depends on the distance from the pollination source and is very high near the trees.

Permanent pollen monitoring in relation to the Cupressaceae family, despite the low allergenicity of this pollen in Poland, is very important for people coming among others from the Mediterranean region.

\section{References}

1. Beggs PJ. Impacts of climate change on aeroallergens: past and future. Clin Exp Allergy 2004, 34: 1507-1513.

2. Ziello Ch, Sparks TH, Estrella $N$ et al. Changes to Airborne Pollen Counts across Europe. Plos One 2012. DOI: 10.1371.

3. Kaplan I, Holt P, Bousquet J, Kay A. Grass, tree, and weed pollen. Allergy and Allergic Diseases 2009, 2(1): 954-958.

4. D'Amato G, Spieksma FThM, Bonini S (eds). Allergenic Pollen and Pollinosis in Europe 1991, Blackwell Scientific Publ. 1991.

5. Ralska-Jasiewiczowa M, Latałowa M, Wasylikowa K et al. (eds). Late Glacial and Holocene history of vegetation in Poland based on isopollen maps. Polish Academy of Sciences, Cracow 2004.

6. Szczepanek K. Pollen calendar for Cracow (southern Poland), 1982-1991. Aerobiologia 1994, 10(1): 65-70.

7. Vanhaelen M, Duchateau J, Vanhaelen-Fastré R, Jaziri M. Taxanes in Taxus baccata pollen: cardiotoxicity and/or allergenicity? Planta Med 2002, 68(1): 36-40. DOI: 10.1055/s2002-19865.

8. Ogren T. The Allergy-Fighting Garden. Berkeley, CA 2015, Ten Speed Press: 205.

9. Burge HA. Monitoring for airborne allergens. Ann Allergy 1992, 69: 9-21.

10. Emberlin J, Savage M, Woodman R. Annual variations in the concentrations of Betula pollen in the London area 1961-1990. Grana 1993, 32: 359-363. DOI: 10.1080/00173139309428965.

11. Maguchi S, Fukuda S. Taxus cuspidata (Japanese yew) pollen nasal allergy. Auris Nasus Larynx 2001, 43-47. DOI: 10.1016/S0385-8146(01)00062-1.

12. Bunderson L, Luvall J, Water P, Levetin E. Juniper Pollen Hotspots in the Southwest. J Allergy Clin Immunol 2013, 131: 2. DOI: 10.1016/j.jaci.2012.12.954.

13. Kalinowska E, Lipiec A, Puc M et al. Analiza stężenia pytku cisu/jałowca w wybranych miastach Polski w 2007 r. Alergoprofil 2007, 3(3): 55-60.

14. Puc M, Myszkowska D, Lipiec A et al. Pyłek cisa i jałowca w powietrzu wybranych miast Polski w roku 2009 r. Wphyw warunków pogodowych i zanieczyszczenia powietrza. Alergoprofil 2009, 5(2): 38-43. 
ORCID

M. Puc - ID - orcid.org/0000-0001-6734-9352

D. Kotrych - ID - orcid.org/0000-0003-4221-2944

M. Malkiewicz - ID - orcid.org/0000-0001-6768-7968

K. Dąbrowska-Zapart - ID - orcid.org/ 0000-0002-8976-7739

D. Myszkowska - ID - orcid.org/ 0000-0002-1493-3990

A. Lipiec - ID - orcid.org/0000-0003-3037-2326

P. Rapiejko - ID - orcid.org/ 0000-0003-3868-0294

A. Stacewicz - ID - orcid.org/0000-0002-3432-8536

Authors' contributions:

Puc M.: 40\%; Kotrych D.: 15\%; Lipiec A.: 5\% and other Authors: 4\% each.

Conflict of interests: The authors declare that they have no competing interests.

Financial support: Does not occur.
Ethics: The contents presented in this paper are compatible with the rules the Declaration of Helsinki, EU directives and standardized requirements for medical journals.

Research in Bialystok, Bydgoszcz, Piotrkow Trybunalski, Opole, Zielona Gora, Warsaw, Wroclaw funded by Allergen Research Center Ltd. (Ośrodek Badania Alergenów Środowiskowych Sp. z 0.0.).

\section{Corresponding author:}

Malgorzata Puc, PhD, Ass. Prof.

Faculty of Biology, University of Szczecin

71-412 Szczecin, Zygmunta Felczaka 3c

e-mail: malgorzata.puc@usz.edu.pl 